\title{
Reflection on Fifty Years of Education in the Population Sciences in Nigeria
}

\section{Chukuka Okonjo \\ Aidgwe Okonjo Centre, Ogbe-Ofu, Ogwashi-Uku, Delta State, Nigeria}

One major contribution of Kenneth Onwuka Dike to historiography, which has not been fully appreciated and internalised by our social (including the population) sciences, is that there is an African viewpoint. Dike's special contribution was to elaborate this viewpoint in history, working out the special methodologies that went with it. This non-internalisation of the Dike lesson would not be surprising, for even the authentic history of Africa - the UNESCO General History of Africa - started in 1965 was only completed in 1999. Similarly, but now to belabour the obvious, there were prior to the colonial domination of the African peoples in the $20^{\text {th }}$ century, African civilisations, thought systems, value systems and an African mode of development. Evidence from the population sciences can be adduced to support this hypothesis. In the case of Nigeria, even though the British seized Lagos in 1861, external colonial domination could be said to have started in 1900, when British sovereignty was proclaimed over the territory called Nigeria. This period has been followed by 39 years of an internal colonialism, which, hopefully, ended on the $29^{\text {th }}$ of May, 1999.

The EREDO earthworks, located near Oke-eri in Ogun State is linked by local tradition to BIRIKISU SUNGBO - also considered by that tradition to be the legendary Queen of Sheba, whose reign is dated by the BIBLE to the $10^{\text {th }}$ century BC and who is said to have had a male child for King Solomon. She is reputed to have been a great queen, childless in her home area and is said to have built this vast monument of remembrance. The earthwork system, the most extensive in the world, involving the shifting of 3.5 million cubic metres of earth to build the encompassing ramparts - that is 1 million cubic metres more than the amount of 
rock, which went into building the Great Pyramid of Cheops in Egypt - is estimated to have taken 150 million man hours to build. This earthwork system, which encloses a vast complex covering 4000 sq. kilometres, divided into 500 communal enclosures goes around the area for 160 kilometres. The vertical side ditches, which are 14 metres in depth are more than 1000 years old, making this the earliest proof of a kingdom founded in the rain-forest area. The earthwork was carried out over a 450 to 650 year period, commencing between 800 to $1000 \mathrm{AD}$., up till the late $15^{\text {th }}$ century, when troops of the Benin kingdom overran much of the surrounding area. (Ahanihu, 1999: 22-23).

The Nigerian historians, SABURI BIOBAKU and J.F. ADE-AJAYI, among others, have visited the site. (Ahanihu, 1999: 23). The Ogun State University, with its headquarters at AGO-IWOYE, is literally a stone's throw away from the site, while the Universities of Ibadan, Lagos, Abeokuta and Lagos State University are each less than $80 \mathrm{~km}$. away. Yet it was left for a British Academy financed mission from the University of Bournemouth, led by the archaeologist PATRICK DARLING, to discover' this WORLD HERITAGE site for the other Nigerians and members of the world community, who have not had the opportunity to visit this site. This and the other findings at Ife, BeninCity, Igbo-Ukwu, the 9000 year old canoe from north-eastern Nigeria and the Nok culture all point to the yawning gap in our research efforts, our knowledge and financing of the study of our past. They also point to major deficiencies in the social science education being imparted. The population agglomerations, cultures and communities indicated by these findings show that there was a high level of independent thought, value systems and mode of development. Evidence would be adduced from the population sciences to support this view.

These remains, of which anyone can be proud, are spread from the rain-forest zone, their fringes, the wooded and grassland savannas, to the extensive plains and arid areas of Northern Nigeria. 
Their location and spatial distribution make it impossible for us to attribute them, not to the indigenous peoples to be found in these areas, but rather as had been the case at the beginning of our period of discussion in the ' $50 \mathrm{~s}$, to people all these areas with fanciful Phoenicians and Carthaginians, who were supposed to be responsible for these high cultures. The writings of Ibn Battuta, the evidence as to their long distance trade with the Mediterranean basin as documented by Hopkins (1973), the five centuries of slave trade, making Africa after Europe the second largest source of settler population outside the continent of origin, as demonstrated by Curtin (1969), as well as their internal trade in ivory, gold, salt and kola nuts among other goods, as detailed by the researches of Polly Hill, (1972) all point to an indigenous origin for these high cultures.

The point perhaps left to be established is whether these remains represent a high point in the cultures of the Western Sudan, after which the original peoples responsible for these artefacts, vanished or became extinct, like the indigenous population of Tasmania. Oral traditions speak of no such extinct peoples neither do the pre-colonial and colonial records. Evidence from the population sciences also seems to suggest that quite a sizeable population has lived in the territorial area covered by Nigeria over the years and particularly at the inception of territorial expropriation and colonial domination by forces alien to these territories, beginning in 1900 .

The population sciences, whose serious study in our tertiary institutions can be said to have begun around 1963, have been and remained an orphan of academic work. As such, no one knows the exact size of the population of Nigeria now or during the period before the onset of colonial domination. Even the officially accepted census figures of 1991 are still a matter for controversy, being regarded by the World Bank as an 11 per cent undercount. The controversy in all these censuses has centred on the relative sizes of the populations to be found in the administrative.areas of 
Northern and Southern Nigeria, amalgamated in 1914 to form the Colony and Protectorate of Nigeria. With independence from external colonial rule in 1960 and the progressive sub-division of the country into 36 territorial units called 'States', the heat generated by the North-South population divide is being increasingly dampened. We can therefore treat the 1991 official population figures as well as those produced by institutions like the World Bank and the United States Bureau of the Census all as representing orders of magnitude of the population. Given this lack of agreement as to what the current population figures are but at the same time the much greater reliance that can be placed on the results of the Post Enumeration Survey (PES) accompanying the 1991 Census, we are entitled to hazard guesses as to the size of the population of Nigeria over the pre-colonial period.

The territorial area now covered by Nigeria is, as part of Tropical Africa, one of the most disease-ridden areas of the world. It is an area, where even as we enter the $21^{\text {st }}$ century malaria, yellow fever and typhoid are rife, if not endemic. The diseases to which indigenes were subject were awesome and included syphilis or yaws, dysentery, leprosy, small pox, schistosomiasis, filiariasis, onchochersiasis, sleeping sickness, gonorrhea and later imports like tuberculosis and cholera. Almost everyone was infected by helminths, which included the hookworm, tapeworm, Ascaris infections and the Guinea worm. Children were particularly subject to the six children killer diseases of neo-natal tetanus, measles, whooping cough, polio, gastro-enteritis and malaria. Non-indigenes like Europeans were particularly susceptible and there were very high death rates of the population of around 40 per 1000 , while infant mortality rates were close on or exceeding 300 per 1000 live births.

These very high rates have not only engendered a response in corresponding high birth rates, but have also given rise to a philosophy of GROUP SURVIVAL. For as the individual, with life expectancies at birth ranging between 20 to 25 years and more 
than half of the children ever born not surviving beyond the age of 5, was expected to die sooner or later, but more 'sooner' than 'later' from the many diseases, occasional famines and warfare, with the social disorganisation this entailed, attention was therefore concentrated not on the survival of the individual but rather on that of the group. This philosophy has also been sustained both by religion and culture, and has meant that the COMMUNITY has become the reference point for the existence of individuals.

It is important in this regard to have an idea of the size of the population, living within the territorial area later to be called Nigeria at the beginning of external colonial domination in 1900. This area was allocated to the British at the Berlin Conference of 1884 - 1885. No one, it must be reiterated, is in a position to give the exact size of the population of Nigeria in 1900 or .provide accurate figures for various dates covering the millenium, which saw the commencement of the Eredo earthworks. Even the current population size of the country is still a matter for controversy. Yet two considerations can lead us to make an informed surmise of the situation with regard to Nigeria's population size in the past, particularly by the year 1900 .

The first of these considerations lies in the nature of exponential growth, which over long periods yields very large numbers from apparently low rates of increase. Thus as Caldwell $(1985 ; 461)$ has pointed out, a growth rate of as low as 0.5 per cent per annum (yielded by a birth rate only five points per thousand above the death rate) results in a fifteen fold increase over a millenium. Thus if the population of Nigeria was around 15 million in 1900, it would not have been more than 1 million a thousand years earlier. The second consideration is the possibility of using stable population methods of analysis. (Brass et al, 1968). This technique was developed at the Office of Population Research of Princeton University in the decade of the $60 \mathrm{~s}$, particularly to solve the problem of estimating African populations from deficient 
data and was aired in Nigeria at the First African Population Conference, held at the University of Ibadan in January 1966.

If the pre-1900 Nigerian population had been stationary, then average death rates would be equal to average birth rates over long periods of time. With a total fertility rate of 5.9 births per woman in 1981/82 (National Population Bureau and World Fertility Survey, 1984), 6.0 births per woman in 1990 (Federal Office of Statistics (FOS) and Institute of Resource Development (IRD), 1992) and 5.9 births per woman in the 1991 Post Census Enumeration Survey (PES), it is clear that fertility has remained virtually the same in the recent past. Calculations from the data of the 1952/53 census by Van de Walle $(1968 ; 515-527)$ lead to a gross reproduction rate of between 3.2 and 3.5 , depending on the assumptions made, or a crude birth rate of between 46 to 52 per thousand live births which also leads to the same conclusion of very high birth rates in the past. Given the disease regime of the pre-colonial era, birth rates could not have been less than 90 per cent of that now found and could certainly not have been less than 80 per cent.

Improving health conditions as those noticed in the post-war era of the decade of the 50 s would lead to a fall in the mortality rates. Mortality has indeed changed fairly linearly, although rather marginally (Hill, 1993) in the recent past and although the NORTH set of model life tables has been used to estimate mortality in Nigeria, none of the existing model life tables perfectly describes the age pattern of mortality in the country (Bicego and Ahmed, 1996) and only an indirect estimation technique ought to have been used for the estimation of mortality data.

If we therefore assume that in the centuries preceding colonial domination population was not stationary but had been growing, albeit very slowly, we can think in terms of a population growing at between a rate of 0.3 to 0.5 per cent per annum over the period, with a slight spurt in growth rates to about 1 per cent per 
annum in the period following the pacification of Nigeria in the period after the First World War and the amalgamation of Northern and Southern Nigeria. Using reverse survival methods on the scanty and not too firm data of the 1952/53 census, the technically accepted but officially rejected 1962 census result of around $45.3 \mathrm{i}$ - million and the 1991 figures, we come out with a population of between 14 to 16 million for the 1900 population of Nigeria.

It must be noted that this figure is of a speculative nature, although It does raise the question of why it was so relatively easy for the imperial power Britain to conquer the territories occupied by so large a population but differently organised from the imperial nation state. The answer must be seen in the Industrial Revolution of the $19^{\text {th }}$ century in Britain and the consequent superiority in military technology possessed by her. We therefore come away from the examination of the population inhabiting Nigeria, before the colonial occupation by the British, at a sizeable population of around 15 million, organised into communities which had developed their cultures, economic underpinnings and socio- political forms of organisations over periods of centuries and whose mode of development has been entitled the African (Nigerian) model by writers like Basil Davidson (1978; 38). These communities differed essentially in form, culture and social organisation from the Western capitalist nation state, which with its superior industrial and military technology overwhelmed them and whose mode of development has been referred to as the European model. (Davidson, 1978; 38).

\section{EDUCATION - Quality, Quantity and Structure}

For most Nigerians, the $20^{\text {th }}$ century has been one of colonial domination, first of external domination up to political independence on October 1, 1960, followed by 39 years of an internal colonialism, 29 of them under military rule. External colonialism established by superior British military technology 
was unable, once the idea of a Nigerian nation state spread in the territorial unit named Nigeria to suppress the movement towards freedom from foreign domination. Political independence had to be conceded. The inheritors of political power, with no viable models of development before them, soon set themselves the task of constructing in Nigeria their own versions of an advanced industrial Western liberal nation state on the lines of their mother country Britain. But administratively equipped with a bureaucracy trained in channeling value from the Nigerian communities to the rulers, in whose benefit the whole colonial scheme was organised, the fledgling 'parliamentary liberal democracy' soon deteriorated into an internal colonialism under military rule for 29 out of the 39 years of political independence that followed.

'Ideas', Chinweizu (1991; 1) has pointed out, 'rule the world'. The British, during their period of political domination of Nigeria, had only succeeded in establishing one tertiary institution and that at Ibadan. This institution in its initial stages did not also engage in the study of the social sciences. There was thus an initial lack of indigenous academic thinkers, who could solve the structural problem of translating a 'nation of communities' into 'a community of one nation'. Without an effective theory of structural change and an effective method of realising it, the inheritance elites gave up all further efforts to resist the tide of privilege and turned their efforts to meeting the demands of primitive accumulation, mobilising their ethnic groups to support their attempts at enriching themselves. Parliamentary systems collapsed under the strain and the military moved in to relieve the country of graft and corruption. But unable to bridge the gap between the few and the many and with time to resist the tide of privilege, their sanitising governments turned into a ruling group dictatorship operating the mechanisms of an internal colonialism.

This internal colonialism has now collapsed. As we now move into the $21^{\text {st }}$ century and the Information Age, the question is being posed once anew - how do we build out of a nation of 97,000 
communities a community of one nation and in the process enable the gap between the rich and the poor, the few and the many to be bridged through modernisaton and accelerated economic development. Two new circumstances now condition the answers which we can give to this question. First, as the Malaysians have found for heterogeneous nation states and Anya $(1997 ; 33)$ has reported, for the endeavour to accelerate economic growth and enhance per capita productivity to succeed, there must be a consistent and discernible commitment to a set of overarching •values, anchored in COMMUNITY and CONSENSUS; secondly, the INFORMATIONAGE into which we are entering does have for its infrastructure an educated population, with this latter condition being reformulated for Nigerian circumstances by the statement that the key to success in the $21^{\text {SI }}$ century is a quality education. (Shonekan, 1998).

Since the original and external colonialism was able to establish itself, because of its superior military technology, it behoves as to examine this question of a 'quality education' a bit critically. A reference to the curricula offered in our primary, secondary and tertiary institutions shows that for a country entering the Information Age, these curricula are deficient in teaching in the sciences, engineering and technology (SET). Further critical examination of the education on offer shows, that it is not only world standards quality education, that must be offered but also an education, which teaches creativity and innovation, promotes competence building in those undertaking it, as well as offering within the system of education a means of self-renewal. If the basis of our search for 'a national resorgimento' is a nation of 97000 communities, each with an ideology of group survival and solidarity as a goal of life, then opportunity must be offered by the new education not only for individual self-fulfillment and self realisation but also for the promotion of community wealth and well being. Having regard also to our putting in place a community of one nation rather than a nation of 97000 communities 
ties, such an education must also promote the attainment of our societal goals as a Nigerian nation.

A continuation of the process of examination of the current education system also shows that not only does it not recognise the right of each community to be educated using its own language and culture, English being the only official language, but it also does not guarantee that every individual would have access to it. In other words, in Nigeria, education is not a fundamental human right.

If we recognise this fundamental human right of all Nigerians to an education with all the characteristics already enumerated above, what does this involve for the community of one nation? First we do have to recognise that apart from the only quaternary institution at Kuru and with the International Institute of Tropical Agriculture at Ibadan being an international organisation, there are no viable quaternary institutions in Nigeria. Secondly, only 0.3 per cent of the age group, which should be undergoing tertiary education, is actually receiving it as against 9 per cent of the same relevant age group in the advanced Western liberal nation states. With regard to secondary education only 17 per cent of the relevant age group is in school, while only some two thirds of those who should be in primary school are in school. Finally, since Nigeria is not operating in the mainstream of world development, we are blissfully unaware of the recent lessons of cognitive science. Thus only some one sixteenth of those aged between 2 to under 6 years are learning how to learn in school, and between 34 to 40 million Nigerians are illiterate and partially innumerate in their mother tongues.

If we are to eliminate these deficiencies within the next five to seven years, we are left with the following awesome agenda which cannot be accomplished by the existing education system functioning the way it is doing now!

$*$ the elimination of the illiteracy and partial innumeracy of 34 to 40 million Nigerians in their mother tongues; 
ensuring that some 15 million children, not already inpre-primary school and aged between 2 to under 6 years are, in addition to the 1 million already there, taught 'learning how to learn';

* making provision for and bringing back to school the one-third of the group aged 6 to under 12, who are not in primary school, thus increasing enrolment from nearly 15 to 22 million;

* $\quad$ providing the facilities and bringing into school the 83 per cent out of those aged 12 to under 18, who should be in secondary school, so that enrolment rises from the current 4.5 million to 20 million and making the teaching of science, mathematics and technology compulsory at this level; increasing tertiary enrolment from the current 474000 to 4,7 million;

* $\quad$ putting in place an infrastructure of 7 Centres of Advanced Studies, 6 basic agro-ecological research institutes, 32 single crop research institutes for quaternary education;

* establishing formally, a 'non-formal system of education, training and retraining' to provide distance and life-long-4 education for all Nigerians.

Given that the crude birth rate is and remains high at 44.55 per thousand live births (NPC, 1998;230) and that the infant mortality rate stood at the unacceptably high level of 93 per 1000 live births, while the childhood mortality rate stood at 64 per 1000 (NPC, 1998;253) it is to be expected that with the aggressive pursuit of mortality reduction, the age structure of our population would continue its 'younging' process and more children than now would have to be enrolled in school. If we should programme for all these anticipated increases at all levels of education, it should be clear that the 'academics approach' to teaching, which now characterises teaching methodology, would have to be replaced by the 'applied academics or contextual teaching approach', more 
suitable for teaching large numbers of children and with more varied learning styles. It would also be necessary, if education for all is to be translated into an affordable reality, for a new educational system with a circular flow of value within it to replace the current system with a 'bottom-top' flow of value, which marginalises considerable proportions of the population.

A third aspect of education also has to be considered, if we do not see education simply in terms of its deficiencies in science and technology or in terms of a study of education history and a systematic comparison of the current education system with other education systems in order to discover the least costly and most cost-efficient options, that should be adopted. We are raising here the question of the basic value variables, which underlie the system. Politics being an attempt to shape society according to a vision of the world, a vision of how things are and how they should be and education an attempt to teach this vision of the world to human beings (Galtung, 1978; 347) the question of the value system underlying the vision becomes a matter of paramount importance. Here all social scientists - historians, sociologists, psychologists, economists, political scientists, philosophers, demographers, practitioners of futures research etc - who study the past, the present and the future need to be concerned.

Consideration of this third aspect of education does direct attention to the fact that education takes place, not in a vacuum, but in a social setting. This setting does have a macro-structure to be seen in the interplay between the legislative and executive arms of government with the education establishments. This interplay results in the rules and regulations governing the operation of the system at various levels, the number of children enrolled at each level of the system as well as the curricula which are taught at the various levels in the many schools. There is also, however, a micro-structure to the education system, seen as the interactions of the schools with its members and the communities within which the schools are located. 
As can be seen here, education is acting as a social mode of educational production and also as a preparation for life as an adult. For the pupil while receiving a vertical form of training in the unquestioning acceptance of authority is also being taught to regard himself with a lower degree of self respect and autonomy. At the same time, the pupil receives horizontal training in competing with others in order to beat them, not in cooperating with them. Moreover, as the pupil moves from one level of education to the other, the same structure of social relations is encountered and through diachronic reinforcement these lessons are firmly internalised. In addition other young persons trained in the same way reinforce these internalised forms of vertical training in the acceptance of authority as well as the horizontal one of competing with and beating others, for they know what to expect as adequate behaviour from themselves as well as others with whom they interact. It would be naive to expect that a young person, who over a period of 16 years of such training in school would emerge as an independent, autonomous, cooperative and democracy loving adult.

\section{The Evolved Societal Model and Value System}

Since the structure of education greatly influences and helps to determine the character of the young adult emerging from it, it is of some importance that we explore this dimension of training further. Given certain values, basic to the training being given, we would be in a position to see the types of society that would evolve and the value system each such society would tend to promote. Interactions between actors or societies coupled together in systems and structures can have differential effects, which benefit the participants in the interaction equally, and so lead to no changes in the relative statuses of the actors or not. ? Where the differential effects on each participant in the interaction is the same, we shall talk of a HORIZONTAL interaction. Where, however, one of the parties to the interaction benefits more, we shall 
talk of a VERTICAL interaction process. This principle of EQUALITY (horizontal) or INEQUALITY (vertical) in the benefits derived by parties from an interaction process can be elevated by a society to a principle for its structural organisation. If we should use more evocative terminology we could talk of JUSTICE being done between the parties to an interaction when the interaction is horizontal one and of INJUSTICE taking place when the interaction is a vertical one.

In like manner, stress can be laid on the 'similarities' between a society's members or the 'dissimilarities' between the parties interacting. In the first case we would be thinking of a society which considers UNIFORMITY (collectivism) or DIVERSIITY (individualism) as principles of organisation. In more evocative terms, we would be talking about FREEDOM and the lack of it as principles of the structural organisation of society. Since education in the social sciences is expected to teach us where we came from, where we are, as also to give us a vision of the preferred state of society to which we would wish to evolve -where we are going - let us using the two variables FREEDOM and JUSTICE and their antonyms classify all societies in the world according to their structures. We have chosen these two basic variables because in the Nigerian national anthem a state in which there is FREEDOM and JUSTICE is preferred. In the same way members of our sister state of Ghana also prefer such a state and so, have placed them as national values on their coat of arms. Using the less evocative equivalents of INEQUALITY (vertical) and EQUALITY (horizontal) and UNIFORMITY (collectivism) and DIVERSITY (individualism) as the organising principles for the structuring of our societies, we obtain following GALTUNG (1978: 322-327) a two by two matrix of ideal societies, which for convenience, we shall call Models I, II, III and IV. 
Table 1. Four Models of Societies (2x2 simple Matrix)

VARIABLE

INEQUALITY

Vertical (Inegalitarian)

(Marx-Engels terminology)

EQUALITY

Horizontal

(egalitarian)
UNIFORMITY

(collectivism)

MODEL I

CONSERVATIVE

(feudal)

MODEL III

COMMUNAL

(socialist)
DIVERSITY

(individualism)

MODEL II

LIBERAL

(capitalist)

MODELIV

PLURALIST

(communist)

(Marx-Engels terminology)

Sociologists would have noted that Talcot Parsons has described the transition from Model I (conservative) to a Model II (liberal) type of society. The Parsonian scheme, however, is silent on the vertical interaction relationships common to both* types of society. In this alternative categorisation, questions of power involving the verticality or horizontality of interactions, questions, which are important in many societies, have been incorporated into the analysis. Each model of society, it should be noted, has its own valid internal logic and social grammar as well as its own method of social reflection (social science). Transition from one model to the other is thus not just a movement along a continuous path, and as such is one of degree along a continuum, but rather involves a basic break or discontinuity in the trajectory of the society in transition. Transition thus implies a radical change in the values of the society in transition, as also in its norms and behaviour as the detailed characteristics worked out in table 2 for each model of society indicates.

We now proceed to use this scheme to categorise the societies of the various nation states of the world. Categorisable as Model I (Conservative) society would be the medieval states of Europe, post-Menelik and pre-Mengistu Ethiopia, Mauritania and modern Japan, excepting for its Model II education system. This has been modified and is now being used to perform ascription functions. Certain aspects of British and French society, where social background still play an important role or as in Japan, where 
education and the degree are used ascriptively, all also belong to this class. Certain organisations like the armed forces of nation states and in the religious sphere, the Roman Catholic Church, all have this same conservative structure.

Classifiable as Model II (Liberal) society are the advanced industrial Western nation states, the so-called modern societies, ranging from the United States of America to other countries like Canada, Britain, France, Germany, Hungary and Bulgaria, to the Soviet Union, while it existed, and Russia now. This model of society contains not only societies with a private capitalist mode of production but also state capitalist ones, as in the case of the Soviet Union. The civil service in a modern nation state and the Protestant Church in religion all offer examples of organisations which have this liberal structure.

Nation states, which can be regarded as good examples of Model III (Communal) society are China, Cuba, Tanzania, Nigeria, Ghana and before the pre-colonial era many sub-Saharan African territories and countries like Mali, the Asante Confederacy, as well as the other empires of the Western Sudan. These latter empires would have been considered territorial units, although most of them in a pro-African revisionist view of history, could be considered as being equivalents to the European bourgeois nation states, although they were however different in social structure from the nation states of Europe. Thus Brodie Cruikshank writing about the Asante Confederacy in 1853 says that it was not a despotism, nor a constitutional monarchy, nor an oligarchy, nor a republic, but partook something of the quality of each of these different forms. It is this model of society, which more truly describes the structural and value systems as well as the norms of many sub-Saharan African countries that Davidson has rightly called the African Model of Development (Davidson, 1978:1-71).

With the industrial revolution in Europe and the consequently emerging technological superiority of the European nation states, particularly in the military sphere, they conquered 
and subjected these differently structured empires, states and territorial units to colonial domination. Since such domination and the sharing out of the various slices of Africa at the Berlin Conference of 1884 - 85 was carried out without the presence and consent of the Africans, the implication was that they, the Africans, were inferior beings. This newly assumed superiority of the Europeans carried itself over into other spheres including sociology and consequently, it was not considered important to study the structures of the pre-colonial societies of the peoples conquered. Moreover, it was assumed that the subjugated territorial units would with time become 'civilised' and would adopt the liberal structural forms of their 'mother countries'. Organisations which have the structure of Model III (Communal) society are the student unions in our universities, in religion the syncretic churches and in sports the football team.

Model IV (Pluralist) society, is one that has not yet been realised. It is a future society in which there is diversity (freedom) and self-realisation, without this being obtained as in Model II (Liberal) society at the expense of equality. Again equality is offered but not as in Model III (Communal) society at the expense of self-individuation or self-actualism.

This scheme presents the notion of development in perspective regarding it as a movement from the past - represented by Model I (Conservative) society - to the present - represented by Model II (Liberal) society and Model III (Communal) society - to Model IV (Pluralist) society. The trajectory of development can thus have two paths from Model I to II to IV or alternatively from Model I to III to IV. It thus transcends much of current development thinking, which still runs in terms of transitions from the traditional (past) or Model I, to the present or modern (Model II) and then on to the future, conceptualised as a linear amplification of Model II society called post-industrial society, with 'equity' being added on to the amplified Model II society in replacement of Model IV society. 
82 Annals of the Social Science Academy of Nigeria, No. 11, January-December, 1999

TABLE 2-FOUR IDEAL MODELS OF SOCIETY (Complex Characterisation)

\begin{tabular}{|c|c|c|c|c|c|}
\hline $\mathrm{S} / \mathrm{N}$ & $\begin{array}{l}\text { Variable } \\
\text { Terminology } \\
\text { (Marx-Engels } \\
\text { terminology) }\end{array}$ & $\begin{array}{l}\text { Model I } \\
\text { Conservative } \\
\text { (Feudal) }\end{array}$ & $\begin{array}{l}\text { Model II } \\
\text { Liberal } \\
\text { [Capitalist } \\
\text { (State, Private)] }\end{array}$ & $\begin{array}{l}\text { Model III } \\
\text { Communal } \\
\text { (Socialist) }\end{array}$ & $\begin{array}{l}\text { Model IV } \\
\text { Pluralist } \\
\text { (Communist) }\end{array}$ \\
\hline 1. & Ethos & $\begin{array}{l}\text { Uniformity } \\
\text { (collectivist) }\end{array}$ & $\begin{array}{l}\text { Diversity } \\
\text { (individualist) }\end{array}$ & $\begin{array}{l}\text { Uniformity } \\
\text { (collectivist) }\end{array}$ & $\begin{array}{l}\text { Diversity } \\
\text { (individualist) }\end{array}$ \\
\hline 2. & Interaction & $\begin{array}{l}\text { Inegal itarian } \\
\text { (Vertical) }\end{array}$ & $\begin{array}{l}\text { Inegal itarian } \\
\text { (Vertical) }\end{array}$ & $\begin{array}{l}\text { Egalitarian } \\
\text { (Horizontal) }\end{array}$ & $\begin{array}{l}\text { Egalitarian } \\
\text { (Horizontal) }\end{array}$ \\
\hline 3. & Basic Structure & $\begin{array}{l}\text { Feudal (only } \\
\text { vertical } \\
\text { interaction) }\end{array}$ & $\begin{array}{l}\text { Class (partly } \\
\text { vertical, partly } \\
\text { horizontal } \\
\text { interaction }\end{array}$ & $\begin{array}{l}\text { Commune } \\
\text { (only } \\
\text { horizontal } \\
\text { interaction) }\end{array}$ & $\begin{array}{c}\text { Pluralist (All } \\
\text { kinds of interact } \\
\text { including } \\
\text { detachment) }\end{array}$ \\
\hline 4. & $\begin{array}{l}\text { Person- Job } \\
\text { Relation }\end{array}$ & $\begin{array}{l}\text { Ascription } \\
\text { heredity } \\
\text { external }\end{array}$ & $\begin{array}{l}\text { Achievement, } \\
\text { ability, internal }\end{array}$ & Participation & Creation \\
\hline 5. & Stratification & Caste, fief & Class & Commune & Plurality \\
\hline 6. & $\begin{array}{l}\text { Vertical } \\
\text { Mobility }\end{array}$ & Seniority & Merit & $\begin{array}{l}\text { None or } \\
\text { Rotation }\end{array}$ & $\begin{array}{l}\text { None or } \\
\text { Rotation }\end{array}$ \\
\hline 7. & $\begin{array}{l}\text { Horizontal } \\
\text { Mobility }\end{array}$ & $\begin{array}{l}\text { Loyalty to } \\
\text { organization }\end{array}$ & $\begin{array}{l}\text { loyalty to self } \\
\text { and toassociation }\end{array}$ & $\begin{array}{l}\text { Loyalty to } \\
\text { commune }\end{array}$ & $\begin{array}{l}\text { Loyalty to } \\
\text { Plurality }\end{array}$ \\
\hline 8. & $\begin{array}{l}\text { Power } \\
\text { Structure }\end{array}$ & \begin{tabular}{|l|} 
Aristocracy \\
Gerontocracy
\end{tabular} & $\begin{array}{l}\text { Meritocracy } \\
\text { (indirect democr.) }\end{array}$ & $\begin{array}{c}\text { Democracy } \\
\text { (direct) }\end{array}$ & $\begin{array}{c}\text { Democracy } \\
\text { (direct or indirect }\end{array}$ \\
\hline 9. & $\begin{array}{l}\text { Decision } \\
\text { Making } \\
\end{array}$ & $\begin{array}{l}\text { Supreme } \\
\text { Authority }\end{array}$ & $\begin{array}{l}\text { Majority vote } \\
\text { of topmost class }\end{array}$ & Consensus & Consensus \\
\hline 10. & $\begin{array}{l}\text { Work } \\
\text { Performance } \\
\text { Style }\end{array}$ & Obedience & Competition & Cooperation & Cooperation \\
\hline 11. & $\begin{array}{l}\text { Implementa- } \\
\text { tion Doctrine }\end{array}$ & Strategy & Strategy & Purpose & Purpose \\
\hline 12. & $\begin{array}{l}\text { Renewal } \\
\text { Process }\end{array}$ & $\begin{array}{l}\text { Approved change } \\
\text { by Supreme } \\
\text { Authority and } \\
\text { imitation of } \\
\text { Superiors }\end{array}$ & $\begin{array}{l}\text { Adversarial } \\
\text { confrontation and } \\
\text { creativity by } \\
\text { topmost } \\
\text { class }\end{array}$ & $\begin{array}{l}\text { Constructive } \\
\text { confrontation } \\
\text { and creativity } \\
\text { by all }\end{array}$ & $\begin{array}{l}\text { Constructive } \\
\text { confrontation } \\
\text { and creativity } \\
\text { by all. }\end{array}$ \\
\hline 13. & $\begin{array}{l}\text { Gender } \\
\text { Relations }\end{array}$ & Patriarchal & $\begin{array}{l}\text { Uni-sex with } \\
\text { male domination }\end{array}$ & $\begin{array}{l}\text { Dual-sex, } \\
\text { cooperation with } \\
\text { female sub } \\
\text { ordination }\end{array}$ & $\begin{array}{l}\text { Equality, } \\
\text { cooperation } \\
\text { with mutual } \\
\text { collaboration }\end{array}$ \\
\hline 14. & Ideology & Inequality & Equality of opportun. & Similarity of life & Equality of life \\
\hline 15. & Goal life & Service & Success & Solidarity & Self-realisation \\
\hline
\end{tabular}

"Source: Adapted from Graining (1978:325 
The notion of development here also has the advantage over all other schemes of seeing all countries and societies as developing. Whatever model of society they now most readily approximate to, they should be engaged in a movement towards creating a Model IV (Pluralist) society. They would however be doing so from different starting points and following different trajectories to their ultimate goal of creating a society, perhaps in the form of the Western nation state, with equity and diversity or one with FREEDOM and JUSTICE, if that terminology is preferred, as organising principles. It is to be noted that the process of development is not seen as automatic as in the Marxian scheme, progressing from Model I to li to III and then to IV. Rather at each stage it is dependent on choices in a continuing political struggle and decision making on issues. Such choices can result in more vertical or horizontal relationships and/or in increased mobility and diversity or the reverse. Accordingly in the new explanatory framework, the nomenclature CONSERVATIVE, LIBERAL, COMMUNAL and PLURALIST has been preferred for Models I, II, III and IV over the feudal, capitalist, socialist and communist nomenclature, which regrettably also now has ideological overtones.

Third World countries, like ourselves, can look a bit more closely at table 2 to see what we can glean from it. In this regard, attention is directed to the variables 'horizontal mobility', 'power structure', 'decision making', 'work performance style', 'gender relations' and 'goal of life' in the table. With regard to migration statistics, the data collected in the population censuses of the advanced Western liberal nation states is based on four typical questions - place of birth, duration of residence, place of last residence and place of residence at a fixed prior date. In contrast in the 1991 census and post-enumeration survey the questions asked were on 'HOME PLACE', DURATION OF RESIDENCE, PLACE OF LAST RESIDENCE and NATIONALITY. (NPC, 1998:265). 
The National Population Commission is to be congratulated for recognising Nigerian realities and seeing that what is meaningful in our situation with its different structural model of society is not where you were born but rather where you are associated with - your HOME PLACE. This they define as "respondents ancestral home", i.e. where his parents and grand parents came from. Where the father and mother have different home places, the home place of the father would be recorded for the children. However in a matrilineal society, where pre-eminence is given to the mother's side, the home place of the mother would be recorded for her children. Furthermore, the homeplace of a woman/wife of head of household is that of her parents and not that of the husband if they don't both come from the same locality (NPC, 1998:266). Thus in Nigerian societies, where one belongs is not simply a biological and geographical phenomenon as in Western liberal society but is rather one containing biological, geographical, sociological and religious elements. For the Nigerian, it is not where you are born, but rather where your ancestors have been buried that determines the group (commune) to which you belong.

With regard to the variable 'power structure', the analysis suggests that liberal societies have a meritocratic power structure and can only at best be regarded as being indirectly democratic. Not all of society participates in the decision making and taking and certain age groups, usually those below the age of 18 , are statutorily shut out from participating in the process of elections, which mark the beginning of decision making in such societies For populations with an ageing population structure, this does mean that only a minority of the population is shut out from the process of decision making and taking, although this group does have wishes that can be ascertained and are peculiar to the group Thus the definition of democracy being 'a government of the people, by the people and for the people' excludes this minority c the population from its very initial procedure of electing the so called government of the people. When it is also remembered that 
Reflection on Fifty Years of Education in the Population Sciences in Nigeria 85

roles in society are assigned according to gender, that politics in most societies is a man's role and that women form around 50 per cent of the population, it would be seen that the so-called 'elected government' in liberal societies actually does not represent more than 35 per cent of the population, mostly male, in the so-called liberal type of democracy.

With countries like Nigeria, the position is even more controversial. For the initially excluded population of those under 18, form the majority of the population. In the case of Nigeria, with the mean age of the population of 17.41 years and a younging population structure, the majority of the population that will be excluded from even the initial process of election would with time become greater, both volume and proportion wise. Thus whomsoever is elected into government has been elected basically by a constituency consisting of the 25 per cent of the population that are males and in effect represents only their interests.

Thus the usually accepted interpretation in a liberal society of democracy as a government of the people, by the people and for the people, turns out to be, in effect, the selection of a meritocracy. They represent the interests of only a limited male constituency. As such, this form of government cannot be satisfactorily operated in a modern communal society. For, in such a society, for the power structure to be democratic, all people must participate directly in taking decisions which affect their lives. There must also be a consensus in the making of decisions. Where however because of the large numbers of people involved direct democracy cannot be practised, the representation of each group concerned in the decision making is ensured and the decisions are taking by representatives in an indirect democracy. But at each level of decision taking decisions are arrived at by consensus. Under such conditions in countries with a 'younging age structure' the age groups excluded from the initial election process can be represented by a group of OMBUDSMEN and. 
OMBDUSWOMEN with equality in the distribution of the representation being observed between the sexes.

Democracy in communal and pluralist societies is thus a process, whereby individuals within the society participate jointly in taking decisions on matters which affect their lives. These decisions are arrived at by CONSENSUS in an atmosphere in which the 'force of argument' not the 'argument offeree' prevails. Where the individual participates in the decision making and taking there is direct democracy. Where, however, the individual does not participate directly but this is done through an accredited representative, there is indirect democracy. Groups that it might be necessary to exclude from the decision making and taking would be represented by OMBUDSMEN and OMBUDSWOMEN.

The differences in the mode of operation of institutions categorised as belonging to Model II and Model III societies are even more marked when their work performance style is considered. While in Model II societies the guiding principle is competition, in Model III societies it is cooperation. Firms or corporations in liberal societies, which are now the foremost organisations for introducing social change into advanced industrial society, are finding that 'competition' and the hierarchical organisation, which it induces, do not generate the biggest profits for their organisations. They are therefore switching their guiding principle to that of cooperation, using a more educated work force and operating a horizontal management system in order to achieve 'fatter bottom lines'. Consequently, the current rage in business schools in the United States is now a combination of the two words COMPETITION and COOPERATION to form a new variable called COOPETITION, which is explained in a book that has proven to be a bestseller in such business schools. In other words, leading firms and corporations in the advanced Model II societies have come to the realisation that COOPERATION among their workers is a better guiding and working principle for realising bigger profits in their operations. 
In the area of gender relations, there are even more marked differences between a Model III society and Model II society. In these latter societies gender relations are uni-sex with a clear ) domination of society by males. Women achieve position and honour by functioning as males. Communal society is however dual-sex in nature (Okonjo, K.:1976). Females are treated as subordinate beings, but a woman can achieve position and honour I in her society functioning as a woman in roles assigned to women.

Thus institutions like MAGAGIYA in North-western, MAGIRA in North-eastern, IYALODE in South-western and OMU in South-central Nigeria as well as the OHEMAA (Queen Mother) in Ghana do not have counterparts in liberal societies. We can therefore think in a participating democracy in terms of a zonning of the electoral constituencies between the sexes. A constituency that elects a man in an election would have at the next election to present a female legislator and vice-versa. Positions in the cabinet would be shared on a basis of around $50 \mathrm{pr}$ cent to each sex. In this connection it is interesting to note that the British from a liberal society, found it difficult to accept that the OGU

UMUNWANYI (Women's War), the so-called Aba Riots in the v-4 relevant colonial literature, was organised and implemented without male participation. Lastly, attention is directed to the fact that the goal of life in Model II societies is SUCCESS, while in Model III societies it is SOLIDARITY with the group to which one belongs.

\section{The Need For A New Education in the Social Sciences.}

These marked differences in the value systems of the institutions of societies which belong to different societal models merits particular attention in countries like Nigeria. There the normal evolution of the societal model - (Model III) - was interrupted and a colonial form of government - essentially a 
conservative/feudal system - imposed on it. In time, forces within Nigerian society succeeded in removing this form of external domination. The inheritors of political power, however, having as their political vision the establishment of a Western capitalist type of society, in turn tried to achieve their ends through a form of government familiar to them. This has however turned out to be the imposition of an internal exploitative colonialism. This new governmental system, in turn, has failed bringing us back, in terms of the structural model - to pre-colonial times. We are thus now faced with the problem of turning a nation made up of 97000 communities (Akinpelu, 1992) to a community of one nation and its further evolution into a community with 'freedom and justice' still before us. That is, we have on our hands a technologically backward Model III structured society, which has still to solve the problems of modernisation and progression towards becoming a pluralist society.

The failure of the two attempts to impose first an external then an internal colonialism on the country, with the ultimate objective of transforming it into a Model II type of society does show that the continued search for higher living standards, a better quality of life and freedom coupled with justice must be in another direction. Two things are essential here. We must have a vision of the world we want to evolve to and a road map leading from where we are to where we want to be. This implies the two fold task of generating the social reflection appropriate to the end model of society that we are trying to evolve into and the detailed changes in current social reflection which have to be made in terms of the new development paths we would have to tread.

Unfortunately, most social (including our population) scientists find it difficult to wean themselves from the liberal thought system in which they have been brought up and to create for us social sciences appropriate to communally structured societies. Thus while we are very learned in western presentations of the past, the present and the desired future, we are extremely 
short on our knowledge of OUR PAST, OUR PRESENT and so are even unable, because of a lack of the appropriate education, to create for ourselves a vision of what our future should be. To exemplify, it is only in 1999, that the academic public at large is having the first authentic history of our past published for us by UNESCO. Moreover, the Eredo earthworks are a part of our past, and what we should know about our past still needs elaboration and amplification.

The task which therefore lies before all our social scientists, is how basing ourselves on the solid foundations of the social structures and value systems already laid for our societies in pre-colonial times in addition to the positive advances made since then, like the reduction of some languages into written script, we can create a new education. This new education must in addition also place before us a road map or a sketch of the development trajectory of our communal societies into a pluralist one. As Davidson (1979: 327) has pointed out using the case of Mali as an example, not only must there be an effective theory of structural change but there must also be an effective practice of realising it.

Certainly, this goal cannot be attained, as the case of Nigeria has shown, through a process of elitist self promotion. The ruling groups must thus sacrifice their specific hopes of power and gain and embrace as their goal the pursuit of the satisfaction of the needs of the masses. Simultaneously, the masses on the other hand must shed themselves of those handicaps arising out of the social structures imposed by our pre-colonial heritage. Thus with the guidance of the teachings of the modern sciences, both social and otherwise, they can adventure with the ruling elite in forming a new national synthesis in the form of an all embracing community with freedom and justice as its principles of organisation.

Attempts at evolving such a theory, which would result in a new national synthesis have been made. Thus through the structural transformation of the economy from below (STEB) engendered by simultaneous and sustainable development through 
empowerment of the people (SISUDEP) in the ten areas of education, science and technology, information and communications, health care, food and nutrition, culture, particularly the languages, income and wealth, employment, community living and the environment as well as participatory democracy, it is hoped that this convergence of the masses and the ruling elites can be achieved.

Most of the areas touched upon by the new STEB through SISUDEP theory are clearly areas in which the social sciences can invent new ideas and innovate intellectually in a framework not too completely different from the past. Since the new theory when applied to the solution of some seemingly intractable problems of development in a country like Nigeria, does provide answers which are acceptable and affordable, it remains to be seen whether Nigerian social scientists would explore the new possibilities open to them.

They could on the one hand after examining the operation of the theory in the fields specified, particularly that of education, insist on an effective practice in realising the theory. On the other hand they could continue as before, to mouth the intellectual shibboleths of a subordinate variant of a decadent Western capitalist thought system refusing to enter the $21^{\text {st }}$ century, and build with the masses 'a Nigeria of one community'.

Members of the $11 *$ General Assembly of the Social Science Council of Nigeria, to borrow an aphorism from the game of tennis - the ball is well and truly back in your court.

\section{References}

Ahanihu, E. (1999) Queen ofSheba and the Ijebu Connection., Th< Guardian, Vol 15, No. 7517, June 12, Oshodi, Lagos.

Akinpelu, J. A. (1992) Education and Mass Literacy, Dangers and Opportunities for Nigeria in the $21^{\text {st }}$ Century Education Today 5(4). Federal Ministry of Education and Youth 
Reflection on Fifty Years of Education in the Population Sciences in Nigeria 91

Development, Lagos.

Anya O. A. (1997) Rebulding the Foundations. Science, Human Capital and Sustainable Development in the $21^{s}$ ' Century - A Nigerian Scenario, Nigerian National Merit Award Winners Lecture, Abuja.

Bicego, G. and O.B. Ahmed (1996) "Infant and Childhood Mortality" DHS Comparative Studies, No. 20. Columbia Maryland: Institute for Resource Development/Macrosystems Inc.

Brass, W. \& J.C. Ansley (1968) The Demography of Tropical Africa. Princeton, University Press

Caldwell, J.C. (1985) The Social Repercussions of Colonial Rule-Demographic Aspects in A.A. Boahen (ed.) UNESCO General History of Africa VIII. Africa under Colonial Domination 1880-1935, California: University Press

Chinweizu (1997) The Reconstruction of Nigeria: Four Delusions on our Strategic Horizon, Seminar on Stabilization of the Nigerian Economy, Centre for Public and Business Policy Enugu.

Curtin P.O. The African Slave Trade: a Census, Wisconsin: University Press.

Davidson, B. Africa in Modern History. The Search for a New Society. Harmondsworth Middlesex: Penguin Books Ltd

Galtung, J. Perspective on Development. Peace and Social Structure. Essays in Peace Research, Christian Eilers Copenhagen, Vol. III.

Hill, A. Trends in Childhood Mortality in Hill K.H. and Forte A eds.). Demographic Change in Sub-Saharan Africa Washington D.C.: National Academy Press.

Hill, P. Rural Hausa, Cambridge University Press

Hopkins, A.G. (1973) An Economic History of West Africa, Longman 
92 Annals of the Social Science Academy of Nigeria, No. II, January - December, 1999

National Population Commission 1991 Population Census of the Federal April, 1998 Republic of Nigeria. Analytical Report at the National Level.

Okonjo, K. The Dual Political System in Operation, Women and Community

Shonekan, E.O.A Quality Education. The Key to Success in the $21^{\text {st }}$ Century.

Van de Walle, E. Fertility in Nigeria in Brass et al. The Demography of Tropical Africa. Princeton: University Press. 